\title{
Retinal Image Analysis System
}

\section{S Karkuzhali*}

Associate Professor, Department of Computer Science and Engineering, Kalasalaingam Academy of Research and Education, Krishnankoil, India

*Corresponding Author: S Karkuzhali, Associate Professor, Department of Computer Science and Engineering, Kalasalaingam Academy of Research and Education, Krishnankoil, India.

DOI: 10.31080/ASOP.2020.03.0091

The human eye is a sensory organ for vision. It is well designed to collect the significant information about the environment around. The retina is the light sensitive tissue that lies in the posterior segment of the eye. It collects light focused from the lens, converts light signal into neural signal and then sends these signals to optic nerve. The optic nerve carries the signal to the brain; it helps to process the image. The color fundus retinal photography records interior surface of the eye that includes retina, retinal vasculature, Optic Disc (OD), macula and posterior pole. It helps to interpret retinal landmarks and is used for the screening of patients suffering from sight-threatening retinal diseases. The fact from World Health Organization (WHO) divulges that almost 285 million people are estimated to be visually impaired, among them 39 million people are blind and 246 million people have low vision. Approximately, $12.3 \%, 8.7 \%$ and $4.8 \%$ of visual impairment are caused by eye diseases like Glaucoma, Age-Related Macular Degeneration (ARMD) and Diabetic Retinopathy (DR). Glaucoma is a degenerative eye disease, in which the optic nerve is gradually damaged due to Intra-Ocular Pressure (IOP) and causes changes in retinal landmarks like OD and Optic Cup (OC), leading to vision loss and eventually blindness. ARMD is an acquired degeneration of retina, in which the non-neovascular (drusen and retinal pigment epithelium) and neovascular abnormalities may be present that lead to impairment of central vision.

Diabetes or Diabetes mellitus is a disease which occurs when the pancreas does not secrete enough insulin or the body is unable to utilize it properly. The disease slowly affects the circulatory system of the human body and retina. As diabetes intensifies, the
Received: January 20, 2020

Published: February 01, 2020

(C) All rights are reserved by $\mathbf{S}$ Karkuzhali. vision of a patient may start to deteriorate and lead to DR. DR is an adverse change in retinal Blood Vessels (BVs) leading to vision loss without any symptoms. Diabetic Macula Edema (DME) is the advanced symptom of DR, and leads to irreversible vision loss. The swelling happens in the macula region due to leakage of fluid from BVs within the macula that appears as the presence of Exudates (EXs) in macula region. Early diagnosis and treatment of retinal diseases are essential to prevent vision loss, and it would significantly reduce the workload for the ophthalmologist.

\section{Assets from publication with us}

- Prompt Acknowledgement after receiving the article

- Thorough Double blinded peer review

- Rapid Publication

- Issue of Publication Certificate

- High visibility of your Published work

Website: www.actascientific.com/

Submit Article: www.actascientific.com/submission.php

Email us: editor@actascientific.com

Contact us: +919182824667 